\title{
Comparative Studies of the Aqueous Extracts of OcimumGratissimum, Aloe Vera, Brassica Oleracea and Ipomoea Batatas on Some Biochemical Parameters in Diabetic Rats
}

\author{
Luka, CarrolDomkat ${ }^{* 1}$,Tijjani, Habibu ${ }^{2}$ \\ ${ }^{1}$ Department of Biochemistry, Faculty of Medical Sciences, University of Jos, Jos, Nigeria \\ ${ }^{2}$ Developmental Biochemistry Research Laboratory, Department of Biochemistry, Bauchi State University,
}

Gadau, Nigeria

\begin{abstract}
The current orthodox treatment modalities for diabetic mellitus have many setbacks including undesirable side effects and the high cost of long term treatment. The aim of this study was to determine the anti-diabetic effectsand compare some biochemical parameters of four plants; Ocimumgratissimum (OG),Aloe vera $(A V)$, Brassica oleracea $(B O)$ and Ipomoea batatas $(I B)$ on alloxan induced diabetic rats. The preliminary phytochemical screening reveals the presence ofalkaloid, tannin, cardiac glycoside, resin and steroids in all four plants. Diabetic was induced by interperitonial injection of alloxan monohydrate while treatment was done for 21 days. Diabetic rats had significant increased $(P<0.05)$ cholesterol, triglyceride $(T G)$, Low Density Lipoprotein $(L D L)$ and artherogenic index (AI). Treatment of experimental rats with $150 \mathrm{mg} / \mathrm{kg} \mathrm{bw}$. of aqueous extractsof plants significantly decrease $(P<0.05)$ the levels of cholesterol and $L D L$ in $O G$ and BO treated groups when compare with the control. Computed artherogenic index was significantly reduced $(P<0.05)$ in $A V$ treated group when compared to the control. Aqueous extracts also significantly $(P<0.05)$ alter serum concentrations of alkaline phosphatase (ALP), alanine aminotransferase (ALT) and aspartate aminotransferase (AST) in a similar manner with metformin treated group. Result showed that decrease in plasma glucose was in the order $I B>O G>B O>A V$. All plant extracts possess antidiabetic, anti-hyperlipidemic effects and were able to ameliorate the weight loss observed in diabetic rats.
\end{abstract}

Keywords:Aloe vera,Brassicaoleracea,Comparativestudies,Diabetics, Ipomoeabatatas, Ocimumgratissimum

\section{Introduction}

Since the beginning of human civilization, medicinal plants have been used by mankind for its therapeutic values. Nature has been a source of medicinal agents for thousands of years and an impressive number of modern drugs have been isolated from natural sources. Many of this isolation were based on the uses of the agent in traditional medicine. The plant-based, traditional medicine system continues to play an essential role in health care, with about $80 \%$ of the world inhabitant relying mainly on traditional medicines for their primary health care [1].

In Nigeria and many other countries of the world, plant parts or herbal preparations are used as herbal drug for the treatment of various ailments. In herbal practices, the practitioners claim that plant parts possess various phytochemicals which exhibit diverse pharmacological and biological responses and diversities [2]. It is also a common practice to use several combinations of herbs (Polyherb) in the treatment of a single disease, a reason why we choose to compare theeffects of the aqueous extract of four plants namely; Ocimumgratissimum, Aloe vera, Brassica oleracea and Ipomoea batatas on some biochemical parameters in diabetic rats.

Several plants have being used traditionally in the treatments of diabetics (Type 1 and Type 2) throughout the world, being a common disease and affecting the citizens of both developed and developing countries[3] it's therefore necessary to document several plants with anti-diabetic activities for easy identification and choice of usage.

Ocimumgratissimum(Lamiaceae)is a common plant in the Savannah and coastal areas of Nigeria, the plant is called "effinrin-nla" by the Yorubas, "Ahuji" by the Igbos, while in the Northern part of Nigeria, the Hausas call it "Daidoya"[4]. The plant is used in the treatment of epilepsy, high fever and diarrhoea [4]. Its traditional uses, morphology, phytochemistry, antihypertensive effect, hepatoprotective effects and more importantly for the purpose of our study, its anti-diabetic activities has been documented in a review by Prabhuet al.,[5]. Mohammed et al., [6] reported the antidiabetic effect of aqueous leave extracts at a dosage of 250,500 and $1000 \mathrm{mg} / \mathrm{kg}$ body weight with $500 \mathrm{mg} / \mathrm{kg}$ significantly lowering blood glucose level.

Aloe vera (barbadensis)belongs to the family Xanthorrhoeaceae, it's a popular plant, planted in gardens and around the household for its therapeutic purpose and as supplements in skin care. Aloe vera has been used as an anti-inflammatory natural agent, for treatment of ulcers, hepatitis and for wound healing[7]. Its antidiabetic effect has been reported by Noor et al., [8]. 
Brassica oleracea(Brassicaceae) is a biannual plant with great importance as human food crop plant. It has been reported that the ethanolic extract has hepatoprotectiveproperties[9]. Ipomoea batatas (Convolvulaceae) has been reported to contain antioxidativecomponents[10] and its white skinned tubers alsoposses' antidiabetic properties [11].In a review on Diabetes and medicinal plants by Kavishankaret al., [3], of the 136listed medicinal plants, Brassica oleracea and Ipomoea batatas were not included, making its necessary to document theirantidiabetic effects. The present study compares the hypoglycemic potentials of the leaves of these plants;Ocimumgratissimum $(\mathrm{OG})$, Aloe vera $(\mathrm{AV})$, Brassica oleracea $(\mathrm{BO})$ and Ipomoea batatas(IB)at $150 \mathrm{mg} / \mathrm{Kg}$ bw. with metformin as a reference drug at $14.2 \mathrm{mg} / \mathrm{Kg}$ bw.

\subsection{Collection of plant materials}

\section{Materials and Methods}

Theplant materials; Ocimumgratissimum (scent leaf), Aloe vera, Brassica oleracea (cabbage) and Ipomoea batatas(sweet potatoleaf) used for this study were obtained from Jos, Plateau state and identified at the Department of Botany, University of Jos before usage.

\subsection{Experimental rats}

The experiment animals used for this study were locally bred Wister strain (Rattusnorvegicus) of both sexes(since diabetics affect males and females) from the animal house of university of Jos, Nigeria. Rats are of body weight between $130-220 \mathrm{~g}$. The animals were maintained under standard environmental conditions, had free access to food (Grand Cereal products, Jos, Nigeria) and water adlibitum. Seven groups of five rats each were randomly distributed in cages and acclimatized for 7 days.

\subsection{Preparation of plant extracts}

The plants (leaves) material were rinsed with tap water and dried by spreading under the shade until a constant weight was obtained. The plant materials were thenpulverized into powder. 50grams of each leaves was soaked separatelyin $100 \mathrm{ml}$ of boiled distilled water and agitatedintermittently for 24 hours. They were then filtered using fine sieve to obtain the aqueous extracts in each case. The extracts were allowed to dry in an oven dryer at $50^{\circ} \mathrm{C}$ to obtain the crude extracts. The extract was stored in an air tight container and was later reconstituted in distilled water to give the required dose of $150 \mathrm{mg} / \mathrm{kg}$ b.wt which was administered during the study.

\subsection{Experimental design}

Group 1: Normal control (positive control)

Group 2: Diabetic control (negative control)

Group 3: Diabetic group, received $14.2 \mathrm{mg} / \mathrm{kg}$ bw of Metformin

Group 4: Diabetic group, received $150 \mathrm{mg} / \mathrm{kg}$ bw of scent leaf extract

Group 5: Diabetic group, received $150 \mathrm{mg} / \mathrm{kg}$ bw of Aloe vera extract

Group 6: Diabetic group, received $150 \mathrm{mg} / \mathrm{kg}$ bw of Cabbage extract

Group 7: Diabetic group, received $150 \mathrm{mg} / \mathrm{kg}$ bw of Sweet potato leaf extract

Each group consist of five animals $(n=5)$.

\subsection{Treatment of experimental animals}

Groups 1 and 2 received $0.2 \mathrm{ml}$ of distilled water per day. Group 3 received Metformin (Jiangsu RuinianQianjin Pharmaceuticals Ltd, China) at $14.2 \mathrm{mg} / \mathrm{Kg}$ bw per day. The extracts $(150 \mathrm{mg} / \mathrm{kg}$ bw) were orally administered once daily for a period of twenty one (21) daysto Groups $4-7$. Blood glucose levels were taken at 7 days interval using One Touch ${ }^{\circledR}$ Glucometre (Life scan Inc. 1995, Milpitas California 95305, USA) to check progress of treatment.

\subsection{Induction of diabetics}

Diabetics mellitus was induced in animals by single intraperitonial injection of $150 \mathrm{mg} / \mathrm{kg}$ body weight of alloxan monohydrate (Sigma, St. Louis, USA) suspended in normal saline, after an overnight fasting. 48 hours later, diabetics were confirmed using One Touch ${ }^{\circledR}$ Glucometre. Animal with fasting blood glucose level $\geq 250 \mathrm{mg} / \mathrm{dl}$ were considered diabetic and included in the study.

\subsection{Collection of samples}

At completion of the 14 days treatment, the rats were subjected to an overnight fast prior to collection of blood samples. The rats were anesthetized at the time of sacrifice by been placed in a seal cotton wool soaked in diethyl ether inhalation jar. Blood samples were collected from orbital plexus venous into centrifuge tubes 
and were allowed to clot for about 45 minutes, after which they were spun at 3000rpm for 5 minutes, the serum collected were transferred into bijou bottle using pasture pipette and kept for analysis.

\subsection{Phytochemicals}

Phytochemical tests were carried out using standard procedures by Harborne[12], Trease\& Evans [13] and Sofowora[14].

\subsection{Assay of biochemical parameters}

Activities of alkaline phosphatase (ALP) were determined by the method of Wright et al., [15] while the activities of alanine aminotransferase (ALT) and aspartate aminotransferase (AST) were assayed by the method of Reitman \& Frankel, [16]. Total cholesterol concentration in the serum was assayed by the method of Fredrickson et al., [17] while serum HDL-cholesterol concentration was determined using the method described by Albers et al., [18]. Serum triglyceride concentration was determined by the method of Hainlineet al., [19]. The atherogenic index was calculated by finding the ratio of the serum Total cholesterol concentration to serum HDL-cholesterol concentration.

\section{Statistical analysis}

Data were presented as Mean \pm SD of 5 replicates and were analyzed using Duncan multiple range test following one-way analysis of variance (ANOVA) using SPSS 16.0 computer software package (SPSS Inc., Chicago, U.S.A). Differences at $\mathrm{P}<0.05$ were considered significant.

\subsection{Phytochemical screening}

\section{Results}

The phytochemical screening of the aqueous extract of Ocimumgratissimum,Aloe vera, Brassica oleracea and Ipomoea batatasindicated the presenceof alkaloid, tannin, cardiac glycoside, resin and steroids in all four plants. Flavonoids were not detected in OG, saponins and balsams were not detected in BO and IB, while phenols were only absent in BO (TABLE 1).

\subsection{Body weight}

Control groups had significant increase $(\mathrm{P}<0.05)$ in final weight while diabetic rats had significant decrease $(\mathrm{P}<0.05)$ in final weight when compared to the initial weights. The reference drug metformin had a similar increase compared to the control as their weight significantly increase $(\mathrm{P}<0.05)$ as seen on the last day of the experiment. OG, BO and IB showed decrease in weight which was however not significant $(\mathrm{P}>0.05)$ when compared to the initial weights. AV showed a significant difference $(\mathrm{P}<0.05)$ from its initial weight (Fig. 1).

\subsection{Glucose level}

Control rats maintained a blood glucose level below $100 \mathrm{mg} / \mathrm{dl}$ throughout the period of the study, while diabetic rats exhibited a gradual increase in plasma glucose to about $500 \mathrm{mg} / \mathrm{dl}$. However, metformin and extracts treated groups showed various patterns in decreasing blood glucose levels with OG and IB competing favourably with the reference drug while AV showed the best response in the decreasing plasma glucose (Fig. 2).

\subsection{Lipid profile}

Total cholesterol was significantly increased $(\mathrm{P}<0.05)$ in diabetic rats. Metformin, AV and IB significantly reverse these increases in total cholesterol while $\mathrm{OG}$ and $\mathrm{BO}$ significantly reduced $(\mathrm{P}<0.05)$ total cholesterol when compared to the control.

Significant decrease and increase in HDL and TG respectively were observed only in diabetic control group while a significant increase $(\mathrm{P}<0.05)$ in $\mathrm{LDL}$ was observed in diabetic control and IB treated group. However, $\mathrm{OG}$ and $\mathrm{BO}$ showed significant decrease $(\mathrm{P}<0.05)$ with $\mathrm{AV}$ and metformin having values comparable to the control groups.

Computed artherogenic index $(\mathrm{CHOL} / \mathrm{HDL})$ had a significant increase $(\mathrm{P}<0.05)$ only in diabetic control while a significant decrease was observed in AV treated group (TABLE 2).

\subsection{Liver enzyme}

Results of ALP shows a significant increase $(\mathrm{P}<0.05)$ in all treated groups with metformin having the least value of $248 \pm 8.64 \mathrm{U} / \mathrm{L}$, while $\mathrm{BO}$ has the highest value of $473 \pm 63.64 \mathrm{U} / \mathrm{L}$. Significant decreases $(\mathrm{P}<0.05)$ 
were observed in all treated groups for ALT and AST except for diabetic rats which had a significant increase $(\mathrm{P}<0.05)$ of $356.85 \pm 11.71 \mathrm{U} / \mathrm{L}$ when compared to the control (TABLE 3 ).

Table 1: Phytochemical screening of Ocimumgratissimum, Aloe vera, Brassica oleracea and Ipomoea batatas Water Extracts

\begin{tabular}{|c|c|c|c|}
\hline Phytochemical & Ocimumgratissimum Aloe vera & $\begin{array}{l}\text { Brassica } \\
\text { oleracea }\end{array}$ & $\begin{array}{l}\text { Ipomoea } \\
\text { batatas (leaf) }\end{array}$ \\
\hline
\end{tabular}

\begin{tabular}{lcccc}
\hline Flavonoids & - & + & + & + \\
Saponins & + & + & - & - \\
Alkaloids & + & + & + & + \\
Phenols & + & + & - & + \\
Resin & + & + & + & + \\
Tannins & + & + & + & + \\
C. Glycosides & + & + & + & + \\
Steroids & + & + & + & - \\
Balsam & + & + & - & + \\
\hline
\end{tabular}

Key $+=$ Present

$-=$ Absent

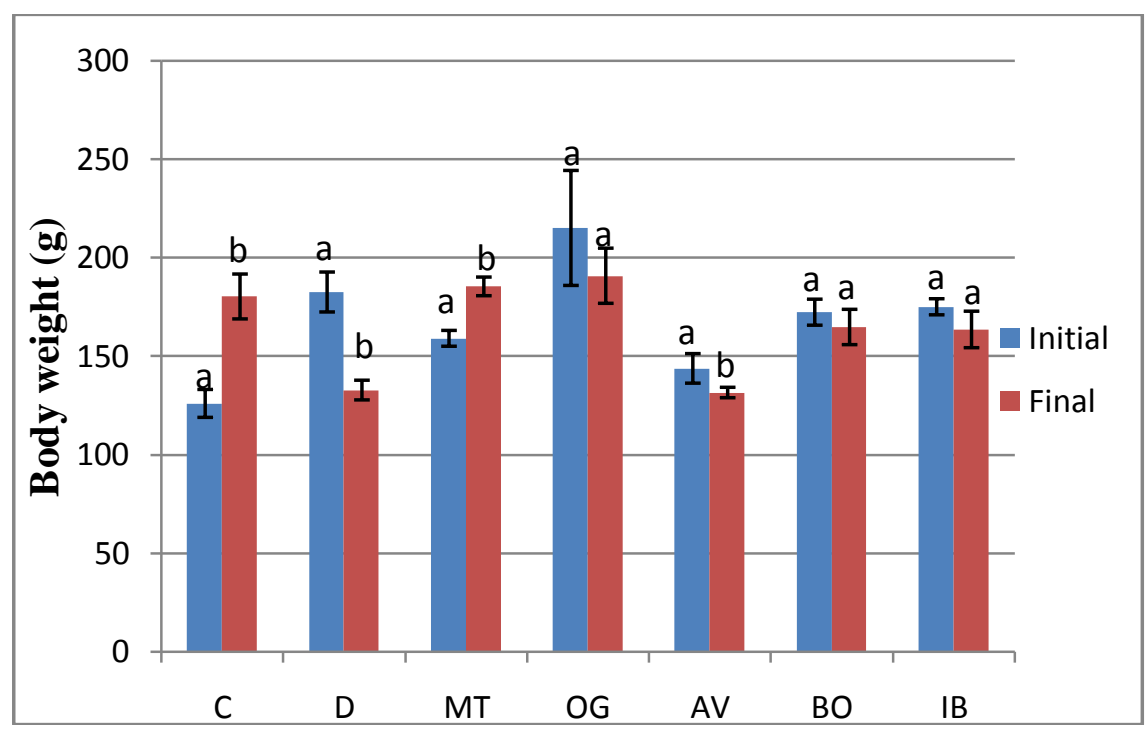

Figure 1: Effect of extracts on body weight

Values are means $\pm \mathrm{SD}, \mathrm{n}=5$. Values with different letter superscripts are significantly different $(\mathrm{P}<0.05)$.

$C=$ Normal Control, $\mathrm{D}=$ Diabetic Control, $\mathrm{MT}=$ Metformin, $\mathrm{OG}=$ Ocimumgratissimum, $\mathrm{AV}=$ Aloevera, $B O=$ Brassica olerace and $I B=$ Ipomoea batatas

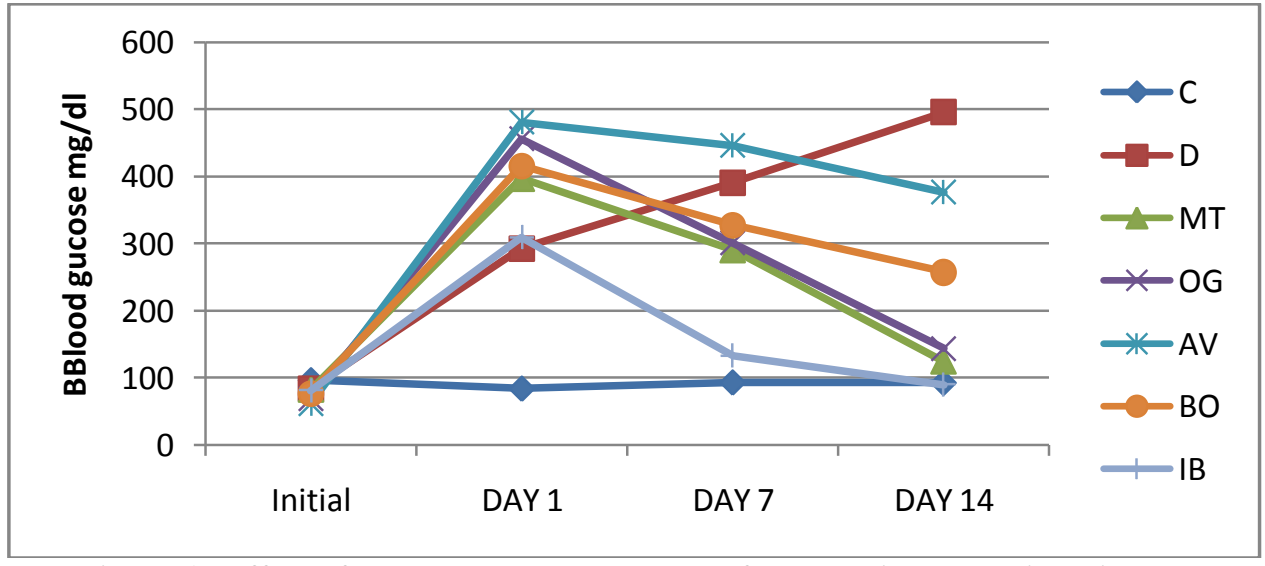

Figure 2: Effect of extracts on glucose level of alloxan-induced diabetic rats

Values are mean, $n=5$ 
$C=$ Normal Control, $\mathrm{D}=$ Diabetic Control, $\mathrm{MT}=$ Metformin, $\mathrm{OG}=$ Ocimumgratissimum, $\mathrm{AV}=$ Aloevera, $B O=$ Brassica oleracea and $I B=$ Ipomoea batatas

Table 2: Effect ofextracts on lipid profile level of alloxan-induced diabetic rats

\begin{tabular}{llllll}
\hline & $\begin{array}{l}\text { CHOL } \\
(\mathbf{m m o l} / \mathbf{L})\end{array}$ & $\begin{array}{l}\mathrm{HDL} \\
(\mathbf{m m o l} / \mathbf{L})\end{array}$ & $\begin{array}{l}\text { TG } \\
(\mathbf{m m o l} / \mathbf{L})\end{array}$ & $\begin{array}{l}\mathrm{LDL} \\
(\mathbf{m m o l} / \mathbf{L})\end{array}$ & AI \\
\hline Normal Control & $2.20 \pm 0.08^{\mathrm{a}}$ & $0.50 \pm 0.08^{\mathrm{a}}$ & $0.90 \pm 0.08^{\mathrm{ab}}$ & $0.80 \pm 0.08^{\mathrm{a}}$ & $2.34 \pm 0.06^{\mathrm{a}}$ \\
Diabetic Control & $2.50 \pm 0.41^{\mathrm{b}}$ & $0.44 \pm 0.02^{\mathrm{b}}$ & $2.68 \pm 0.07^{\mathrm{c}}$ & $1.52 \pm 0.02^{\mathrm{b}}$ & $5.04 \pm 0.27^{\mathrm{b}}$ \\
Metformin & $2.07 \pm 0.61^{\mathrm{a}}$ & $0.95 \pm 0.37^{\mathrm{a}}$ & $0.52 \pm 0.06^{\mathrm{a}}$ & $0.91 \pm 0.12 \mathrm{a}$ & $2.09 \pm 0.35^{\mathrm{a}}$ \\
Ocimumgratissimum & $1.65 \pm 0.13^{\mathrm{c}}$ & $0.87 \pm 0.88^{\mathrm{a}}$ & $0.46 \pm 0.09^{\mathrm{a}}$ & $0.43 \pm 0.05^{\mathrm{c}}$ & $1.99 \pm 0.31^{\mathrm{a}}$ \\
Aloe vera & $2.20 \pm 0.22^{\mathrm{a}}$ & $1.22 \pm 0.07^{\mathrm{a}}$ & $1.06 \pm 0.10^{\mathrm{b}}$ & $0.66 \pm 0.15^{\mathrm{a}}$ & $1.50 \pm 0.02^{\mathrm{c}}$ \\
Brassica oleracea & $1.74 \pm 0.13^{\mathrm{c}}$ & $0.92 \pm 0.12^{\mathrm{a}}$ & $0.67 \pm 0.07^{\mathrm{ab}}$ & $0.55 \pm 0.08^{\mathrm{c}}$ & $1.79 \pm 0.34^{\mathrm{a}}$ \\
Ipomoea batatasleaf & $2.10 \pm 0.70^{\mathrm{a}}$ & $1.05 \pm 0.08^{\mathrm{a}}$ & $1.57 \pm 0.19^{\mathrm{b}}$ & $1.00 \pm 0.71^{\mathrm{ab}}$ & $2.02 \pm 0.43^{\mathrm{a}}$ \\
\hline
\end{tabular}

Values are means $\pm S D, n=5$. Values in each column with different letter superscripts are significantly different $(\mathrm{P}<0.05)$.

$\mathrm{CHOL}=$ Total cholesterol; $\mathrm{HDL}=\mathrm{HDL}-$ cholesterol $; \mathrm{TG}=$ triglyceride $; \mathrm{LDL}=\mathrm{LDL}-$ cholesterol; $\mathrm{AI}=$ Artherogenic index

Table 3: Effect of extracts onsome liver enzymes of alloxan-induced diabetic rats

\begin{tabular}{llll}
\hline & ALP $(\mathbf{U} / \mathbf{L})$ & ALT $(\mathbf{U} / \mathbf{L})$ & AST $(\mathbf{U} / \mathbf{L})$ \\
\hline Normal Control & $218.00 \pm 0.82^{\mathrm{a}}$ & $123.33 \pm 1.25^{\mathrm{a}}$ & $274.33 \pm 1.25^{\mathrm{a}}$ \\
Diabetic Control & $354.50 \pm 15.09^{\mathrm{b}}$ & $99.58 \pm 5.97^{\mathrm{b}}$ & $356.85 \pm 11.71^{\mathrm{b}}$ \\
Metformin & $248.00 \pm 8.64^{\mathrm{c}}$ & $42.63 \pm 3.63^{\mathrm{c}}$ & $52.47 \pm 2.52^{\mathrm{c}}$ \\
Ocimumgratissimum & $407.00 \pm 10.86^{\mathrm{d}}$ & $16.60 \pm 2.27^{\mathrm{d}}$ & $47.20 \pm 9.63^{\mathrm{c}}$ \\
Aloe vera & $449.50 \pm 9.47^{\mathrm{e}}$ & $33.30 \pm 4.74^{\mathrm{c}}$ & $90.40 \pm 2.34^{\mathrm{d}}$ \\
Brassica oleracea & $473.00 \pm 63.64^{\mathrm{e}}$ & $39.88 \pm 4.21^{\mathrm{c}}$ & $92.85 \pm 11.13^{\mathrm{d}}$ \\
Ipomoea batatasleaf & $453.25 \pm 58.09^{\mathrm{e}}$ & $37.73 \pm 2.72^{\mathrm{c}}$ & $95.58 \pm 0.66^{\mathrm{d}}$ \\
\hline
\end{tabular}

Values are means \pm SD, $n=5$. Values in each column with different letter superscripts are significantly different $(\mathrm{P}<0.05)$

\section{Discussion}

Alloxan monohydrate is known to induce diabetes by partial destruction of pancreatic beta cells of the islet of langerhan[20,21], this result in depletion of insulin levels and hyperglycemiaresults, leading to type 1 diabetes mellitus. The alloxan treated rats therefore represents a good laboratory model for insulin dependent diabetics mellitus (IDDM). The classical symptoms of diabetes includespolyurea, polydipsia, polyphagia and weight loss[22].The wetness and odour of the cages containing the alloxan-induced diabetic rats observed during the first five to eight days of the study was due to the polyuria which is a symptom of acute diabetics mellitus.Proteolysis, lipolysis and acute fluid loss during diabetics may also be responsible for weight loss [23] as observed in Fig. 1. Aqueousextracts from $\mathrm{OG}, \mathrm{BO}$ and IB significantly $(\mathrm{P}<0.05)$ reverse these lost in weightobserved in diabetic rats.

The results of this study revealed the presence of several phytochemicals. Analysis of these plants extracts indicated appreciable amount of alkaloid, tannin, cardiac glycoside, resin and steroids in all plant materials. However, flavonoids were not detected in OG, saponins and balsams were not detected in BO and IB, while phenols were only absent in BO (TABLE 1). Phytochemicals screening of OGand BO were similar to the once reported by Prabhuet al., [5] and Ahmed et al., [9] respectively.

Over 150 plants extracts and some of their active principles include flavonoids are known to be used for the treatment of diabetes [24]. Moreover, tannin contains drugs demonstrated antidiabtetic activity [25].The fact that plants are endowed with a variety of phytochemicals or bioactive compounds that are thought to act on a variety of targets by various modes and mechanisms [26, 27] make these plants and their phytochemical components a source of anti-hyperglycemic agents.Saponin, flavonoids and tannins are reported to exhibit various hypergycemiceffects, increasing pancreatic secretions of insulin and may also participate in increased peripheral uptake of glucose [28, 29].

The antidiabtetic test shows that the $150 \mathrm{mg} / \mathrm{kg}$ of these plants extracts Ocimumgratissimum,Aloe vera, Brassica oleraceaand Ipomoea batatas reduced the blood glucose level in the treated diabetic animals when 
compared with the diabetic control. Each groups of plants extracts had a significantly reduced level of glucose unlike the increased level of glucose observed in the diabetic animals. OG, MT, and IB competed in a likely manner, reducing the plasma glucose levelto below $250 \mathrm{mg} / \mathrm{dl}$. BO was however better in reducing the glucose levels compared to AV.

The results of the lipid profile showed that the $150 \mathrm{mg} / \mathrm{kg}$ of these plants extracts Ocimumgratissimum,Aloe vera, Brassica oleraceaand Ipomoea batatassignificantly $(\mathrm{P}<0.05)$ reduced the total cholesterol, triglyceride and low density lipoprotein, compared to the diabetic control. The high density lipoprotein which was reduced in the diabetic control was significantly increased $(\mathrm{P}<0.05)$ in each group of rats that was administered with Ocimumgratissimum,Aloe vera, Brassica oleraceaand Ipomoea batatas plants extracts. The major complications in diabetes include aberrant lipid metabolism and vascular wall function. Since alterations in serum lipid profile are known in diabetes which is likely to increase the risk of coronary heart disease, a reduction in serum lipids particularly total cholesterol, triglyceride and low density lipoprotein level should be considered as a beneficial in long term prognosis of diabetic patients. Many plants extracts have the potential therapeutic value in combating multifactorial artherosclerotic disorder[30], which are parts of the major complications of diabetes. Reducing the risk of arthrosclerosis will thus lead to the development of effective and better management of hyperlipedemia. All plant extracts administered reduced the risk of atherosclerotic as observed by the computed AI. The best being AV and the least was IB. The atherogenic index (total cholesterol/HDL-cholesterol) is a reliable and strong indicator of cardiovascular diseases. Myocardial infarction increases considerably when the ratio is higher than 5 [31]. The ratios observed in this study were less than half of this value in all administered extracts and were not significantly different $(\mathrm{P}>0.05)$ when compared to the control except for AV which was significantly reduced (TABLE 2), suggesting that the extracts may not predispose subjects to coronary heart disease, thereby not giving rise to further cardiovascular complications during the diabetic treatment.

This study reveals that the plants extracts (Ocimumgratissimum,Aloe Vera, Brassica oleraceaand Ipomoea batatas)at $150 \mathrm{mg} / \mathrm{kg}$ bw. Significantlyreduced $(\mathrm{P}<0.05)$ the levels of aspartate aminotransferase and alanine aminotransferase when compared with the diabetic control where cytosolic leakages of AST and ALP were observed.ALP was increased in the diabetic control as well as each group of rats that were administered with all plants extracts, it was however reduced in metformin treated group.During hepatic damage, cellular enzyme like AST, ALT and ALP present in the liver cell may leak into the serum resulting to increase their concentrations [32]. The results obtain in this study are similar to the reference drug, this may be due to the protective effect of extracts on liver cells.

\section{Conclusion}

It is evident from this studies that all aqueous plant extracts possess antidiabetic and anti-hyperlipidemic effects. The extracts were also able to ameliorate the effects of weight loss as observed in diabetic rats. The hypoglycemic effect was in the order IB $>\mathrm{OG}>\mathrm{BO}>\mathrm{AV}$. The aqueous extracts may be completely safe at the dosage administered due to their effects on assayed marker enzymes. Further studies areon-going in our laboratory to document their possible synergetic or antagonistic effects.

\section{References}

[1] J. Owolabi,E.K.I. Omogbai,andO. Obasuyi, Antifungal and antibacterial activities of the ethanolic and aqueous extract of Kigeliaafricana (Bignoniaceae) stem bark, Afr. J. Biotechnol,6 (14), 2007, 882-85.

[2] P. E. Albert and V. Francis, African Natural Plant Products; New Discoveries and Challenges in Chemistry and Quality, 7, 2009, 135147.

[3] G.B. Kavishankar, V. Lakshmidevi, M.N. Mahadeva,H.S.Prakash,S.R. Niranjana,Diabetes and medicinal plants-A review, Int J Pharm Biomed ScI,2(3), 2011, 65-80.

[4] K.D. Effraim, T.W. Jacks., O.A. Sodipo,Histopathological studies on the toxicity of Ocimumgratissimumleave extract on some organs of rabbit,Afr J Biomed Res, 6, 2003, 21-5.

[5] K.S. Prabhu, R. Lobo, A.A. Shirwaikar, and A.Shirwaikar, Ocimumgratissimum: A Review of its Chemical, Pharmacological and EthnomedicinalProperties, The Open Complementary Medicine Journal,1, 2009,1-15.

[6] A. Mohammed, Y. Tanko, M. A. Okasha,R.A.Magaji, and A.H. Yaro,Effects of aqueous leaves extract of Ocimumgratissimumon blood glucose levels of streptozotocin induced diabetic wistarrats, Afr J Biotechnol, 6, 2007, 2087-90.

[7] A.A. Oryan, A.T. Naeini, B. Nikahval, and E. Gorjian, Effect of aquoues extract of Aloe vera on experimental cutaneous wound healing in rats, Vet. Arhiv,80, 2010, $509-522$.

[8] A. Noor, S. Gunasekaran, A. Manickam, and M. Vijayalakshmi.Antidiabetic activity of Aloe veraand histology of organs in streptozotocininduced diabetic rats,Curr. Sci., 94, 2008, 1070-1076.

[9] M.F. Ahmed, A. Srinivasa,S.R.Ahemad, and M. Ibrahim,Protective Effect of Brassica oleracea L. var. capitataagainst Simvastatin Induced Hepatotoxicity in Rats,Int. Res. J. of Pharmaceuticals, 02(04), 2012, 91-97.

[10] F. Hayase, and H. Kato,Antioxidative components of sweet potatoes, J. Nutritional Science and Vitaminology, 30, 1984, 37-46.

[11] S. Kusano, and H. Abe,Antidiabetic activity of white skinned sweet potato (Ipomoea batatasL.) in obese Zucker fatty rats, Biological and Pharmaceutical Bulletin,23, 2000, 23-26.

[12] J. B. Harborne,Phytochemical Methods. Chapman and Hall Ltd., London1973, 49-188.

[13] G. E. Trease,andW.C. Evans,Pharmacognosy, 11thedn., BailliereTindall, London, 1989, 45-50.

[14] A. Sofowora, Medicinal plants and traditional medicine in Africa, Spectrum Books Ltd., Ibadan, Nigeria, 1993,289.

[15] P.J. Wright,P.D. Leathwood,andD.T. Plummer,Enzymes in rat urine, Alkaline phosphatase. Enzymologia,42, 1972, 317-327. 
[16] S. Reitman,andS. Frankel, A colorimetric method for the determination of serum glutamic oxaloacetic and glutamic pyruvic transaminase, American Journal of Clinical Pathology,28, 1957,56-63.

[17] D.S. Fredrickson,R.I. Levy, and R.S. Lees,Fat transport in lipoproteins-An integrated approach to mechanisms and disorders, New England Journal of Medicine,276, 1967, 148-156.

[18] J.J Albers, G.R. WarmickandM.C. Cheung, Quantitation of high density lipoproteins. Lipids, 13, 1978, 926-932.

[19] A. Hainline, G.R. Cooper, and A.S. Olansky,CDC survey of high density lipoprotein cholesterol measurement: A report, Center for Disease Control publication, Atlanta, GA. 1980

[20] I.C. Cakici, B. Hurmoglu,N. Tunctan,A.I. Kanzik,andB. Sener, Hypoglycemic effect of Momordicacharantiaextract in normoglyccemicmice,J. thnopharmacol.,44, 1994, 117-121.

[21] J.A. Abdel-Barry, I.A. Abdel-Hassan, and M.H. Al-Hkiem, Hypoglycemic and antihyperglycemic effects of Trigonellafoenumgracumleaf in normal and alloxan induced diabetic rats,J.Ethnopharmacol.,58, 1997,149-55.

[22] D.W. Cooke,andL. Plotnick,"Type 1 diabetes mellitus in pediatrics", Pediatr Rev, 29 (11), 2008, $374-84$

[23] K.G.M.M. Alberti, and P.Z. Zimmet, Diagnosis and Classification of Diabetes Mellitus and its Complications, Part 1: Disguises and Classification of Diabetes Mellitus Provinsional Report of WHO consultations,Diabet. Med.,15, 1998, 539-553.

[24] A. Sofowara, Medical Plants and Traditional Medicine in Africa, Rep. Edition, Spectrum Books Ltd., Ibadan, $2006 ; 150$.

[25] M.M. Iwu,Hypoglycemic properties of Brideliaferruginea leaves, Fitoterapia,54, 1983, 243-248.

[26] A.K. TiwariandJ.M. Rao,Diabetic mellitus and multiple therapeutic approaches of phytochemicals: Present status and future prospects,Curr. Sci.,; 83, 2002, 30-37.

[27] S.W. Zito, J. Shinde,T. Taldone,andM. Barletta, Oral hyperglycemics: a review of chemicals used to treat type 2 diabetes,Curr. Bioactive Compds, 4, 2008, $68-85$.

[28] S. Bajaj and B.P. Srinivasan. Investigations in to the anti-diabetic activity of Azadirachtsindica, India J. Pharmacol.,31, 1999, 138141.

[29] L. Pari, R. Ramakrishnan, and S., Venkateshwaran.Antihyperglycaemic effect of Diamed, a herbal formulation, in experimrntal diabetes in rats, J. Pharm. Pharmacol.,53, 2001, 1139-1143.

[30] U. Lindequist,T.H.J. Niedermeyer,and W.D. Julich, The pharmacological potential of mushrooms,Evid Based Complement Alternat Med,2, 2005, 285-99.

[31] M. Boers, M.T. Nurmohamed, C.J. Doelman, L.R. Lard, A.E. Verhoeven, andA.E. Voskuyl,Influence of glucocorticoid and disease activity on total and high density lipoprotein cholesterol in patients with rheumatoid arthritis, Ann Rheum Dis,62, 2003, 842-5.

[32] A. C. Deb,Fundamentals of biochemistry. 7th ed. Kolkata, New Central Book Agency, 1998. 